\title{
Characterization of bombesin receptors in peripheral contractile
} organs

\author{
N. Rouissi, N.-E. Rhaleb, F. Nantel, S. Dion, G. Drapeau \& ${ }^{1}$ D. Regoli \\ Department of Pharmacology, Medical School, University of Sherbrooke, Sherbrooke, Canada J1H 5N4
}

1 Guinea-pig and rat urinary bladders, rat stomach and the guinea-pig gall bladder, four isolated organs that show high sensitivity to bombesin, were used to characterize bombesin receptors in peripheral organs.

2 The order of potency of agonists was determined with several naturally occurring peptides of the bombesin series, namely bombesin (BBS), litorin (Lit), neuromedin B (NMB), the gastrin-releasing peptide (GRP 18-27), neuromedin C (NMC) and with some bombesin fragments. It was found that bombesin, neuromedin C, litorin and two bombesin fragments, BBS (6-14) and AcBBS (6-14) had similar activities in the four preparations, while neuromedin $\mathrm{B}$ and $\left[\mathrm{Phe}^{6}\right]$-neuromedin $\mathrm{C}$ were more active on the rat urinary bladder than on the other tissues.

3 The order of potency of agonists determined in the rat urinary bladder was as follows: BBS $=$ NMB $>$ Lit $>$ NMC $>\left[\right.$ Phe $\left.^{6}\right]$ NMC $=$ GRP and it was found to be different from that observed in the other preparations: $B B S>$ GRP $=$ Lit $\geqslant N M C \gg N M B>\left[P^{6} e^{6}\right] N M C$, suggesting the existence of two different bombesin receptors, $\mathrm{BBS}_{1}$ and $\mathrm{BBS}_{2}$.

4 This interpretation was convalidated by the finding that bombesin antagonists, namely Ac.GRP(2026) $\mathrm{OCH}_{3}$ and Ac.GRP(20-26) $\mathrm{OC}_{2} \mathrm{H}_{5}$ reduced or blocked the effects of bombesin-related peptides on BBS $_{2}$ receptor systems while being completely inactive on the rat urinary bladder (BBS 1 system).

Keywords: Bombesin; receptor subtypes; antagonist; smooth muscles

\section{Introduction}

Bombesin is a tetradecapeptide isolated from amphibian skin (Anastasi et al., 1971), and shown to have similarities to litorin (Anastasi et al., 1975) and other mammalian peptides, the gastrin releasing peptide (GRP) (McDonald et al., 1979), neuromedin B (NMB) (Minamino et al., 1983) and neuromedin C (NMC), (Minamino et al., 1984).

Bombesin and its homologues exert a variety of biological effects both on the central nervous system and in peripheral organs; they modulate thermoregulation (Brown et al., 1977), activate gastric, pancreatic or intestinal secretions (Bertaccini et al., 1973; Girard et al., 1984; Otsuki et al., 1987 and see also Jensen et al., 1988a) and motility (Erspamer et al., 1970; Erspamer \& Melchiorri, 1973; Girard et al., 1984; Severi et al., 1988).

Erspamer et al. (1970) first observed that bombesin has a stimulant effect on isolated smooth muscles. More recently, Falconieri-Erspamer et al. (1988) have shown that litorin and phyllolitorin (two bombesin homologues) are potent stimulants of the rat urinary bladder but are rather weak on other smooth muscle preparations, which however show high sensitivity to bombesin. They concluded that multiple bombesin receptor types may be present in peripheral organs. Studies with antagonists, both the substance P (SP)-analogues (Jensen et al., 1984; Regoli et al., 1988) and the pseudopeptide analogues of bombesin (Jensen et al., 1988a,b) have provided further indication that BBS and related peptides may act on two different receptor types.

Recent developments in the field of bombesin antagonists have centred on the GRP $(20-26)$ sequence. Heimbrook et al. (1989) have shown that GRP $(20-26) \mathrm{OCH}_{3}$ and GRP (20-26) $\mathrm{OC}_{2} \mathrm{H}_{5}$ competitively block the binding of GRP to Swiss $3 \mathrm{~T} 3$ mouse fibroblasts.

In this study, we have attempted to characterize bombesin receptors by using a few bombesin homologues and fragments as well as some antagonists bearing the GRP (20-26) sequence. These peptides were tested on four smooth muscle preparations, the rat and guinea-pig urinary bladders (RUB;

\footnotetext{
${ }^{1}$ Author for correspondence.
}

GPUB), the rat stomach (RS) and the guinea-pig gall bladder (GPGB).

\section{Methods}

The experiments were carried out on tissues taken from rats (albino, Sprague Dawley, 200-300 g) and guinea-pigs (albino, $200-300 \mathrm{~g}$ ) killed by stunning and exsanguination through sectioning of the carotid arteries. The organs were rapidly taken out and plunged in oxygenated Tyrode solution of the following composition (in $\mathrm{mM}$ ): $\mathrm{NaCl} 137.0, \mathrm{KCl} 2.7, \mathrm{CaCl}_{2} .6 \mathrm{H}_{2} \mathrm{O}$ 1.8, $\mathrm{MgCl}_{2} .6 \mathrm{H}_{2} \mathrm{O} 1.05, \mathrm{Na}_{2} \mathrm{HPO}_{4} 0.4, \mathrm{NaHCO}_{3} 11.9$ and dextrose 5.6. Strips of the four organs were prepared according to the procedure described by Vane (1957) for the rat - stomach. The strips were then suspended in $10 \mathrm{ml}$ organs baths containing Tyrode solution oxygenated with $95 \% \mathrm{O}_{2}$ and $5 \% \mathrm{CO}_{2}$ and $\mathrm{kept}$ at $32^{\circ} \mathrm{C}$. A tension of $1 \mathrm{~g}$ was initially applied to the strips of GPUB, RUB and RS and $0.5 \mathrm{~g}$ to those of GPGB. Tissues were allowed to equilibrate for 60 to 80 min during which time they were washed and the tension readjusted at $15 \mathrm{~min}$ intervals. Changes of tension produced by bombesin and other substances were recorded isometrically with Grass force transelucers (FTO3C) on Grass polygraphs (Model 7D).

\section{Experimental protocols}

Concentration-response curves for bombesin and several fragments and homologues were obtained by applying consecutively increasing concentrations of each peptide up to $10^{-5} \mathrm{M}$. The maximal response was measurable for the majority of the peptides at this concentration. Large variations in the maximal responses to the various peptides were observed in some of the tissues (for instance the rat stomach) and the maximal response of each preparation to BBS was taken as $100 \%$, knowing that $\alpha^{\mathrm{E}}$ in this condition is purely an empirical parameter useful to compare maximal effects of agonists. Peptide affinities were calculated from a minimum of six concentration-response curves and are expressed in terms of $\mathrm{pD}_{2}$, the negative logarithm of the concentration of peptides that produces $50 \%$ of the maximum effect of each compound. 
This method of calculation inevitably leads to underestimating the activities of the potent $\left(\alpha^{\mathrm{E}}\right.$ higher than 1.0) and to overestimating those of the weak ( $\alpha^{\mathrm{E}}$ lower than 1.0) peptides. Relative activities are expressed as a percentage of that of bombesin.

Apparent affinities of antagonists $\left(\mathrm{pA}_{2}\right.$, the negative logarithm of the concentration of antagonist that reduces the effect of a double dose of agonist to that of single dose; Schild, 1947) were determined by measuring biological responses to BBS in the absence and in the presence of the antagonist, the latter being added 7-8 min before measuring the effect of bombesin. Higher concentrations of some antagonists were also tested to estimate $\mathrm{pA}_{10}$ values and evaluate the competitivity of the antagonists from the $\mathrm{pA}_{2}-\mathrm{pA}_{10}$ difference, according to Schild (1949). Schild plots were calculated according to Schild (1949) for the two antagonists.

In other experiments, peptidase inhibitors, namely captopril $\left(1 \times 10^{-6} \mathrm{M}\right)$, thiorphan $\left(2.3 \times 10^{-6} \mathrm{M}\right)$ and bestatin $\left(10^{-6} \mathrm{M}\right)$ were tested on the rat stomach, the rat urinary bladder and the guinea-pig urinary bladder, according to Rouissi et al. $(1990 \mathrm{a}, \mathrm{b})$. In short, the effects of average high concentrations of each peptide were measured in the absence and presence of the peptidase inhibitor. These compounds were applied 20 to 30 min before testing the peptide in order to obtain a stable inhibition of the intramural enzymes.

\section{Peptides and other drugs}

Bombesin, litorin, neuromedin C, neuromedin B were purchased from Bachem; human GRP (1-27) was a gift from Dr S. St-Pierre, INRS, Montreal; BBS (6-14), Ac-BBS (6-14) Ac-GRP (20-26) $\mathrm{OCH}_{3}$, Ac-GRP (20-26) $\mathrm{OC}_{2} \mathrm{H}_{5}$, Ac-GRP (20-26), Ac-[D-Phe $\left.{ }^{12}\right]$-BBS (6-14), [Phe $\left.{ }^{6}\right]$-neuromedin $\mathrm{C}$ bradykinin and angiotensin II were prepared in our laboratory by $\mathrm{Dr}$ G. Drapeau by the solid-phase method (Drapeau \& Regoli, 1988). The primary structures of the bombesinrelated peptides are shown in Table 1 . Peptides prepared in our laboratory were purified by high pressure liquid chromatography and their structures were assessed by fast atomic bombardment (FAB) mass spectrometry.

Atropine, methysergide, indomethacin, acetylcholine and histamine were purchased from Sigma, EDTA from Fisher and 3-amino-1-[m-(trifluoromethyl)-phenyl $] 2$ pyrazoline (BW 755C) was a gift from Dr S. Moncada of Burroughs-Welcome. Thiorphan was purchased from Institut Armand Frappier Biochem International Inc., bestatin from Sigma and captopril was a gift from Dr J.G. Joly of Squibb Canada.

Concentrated solutions $\left(1 \mathrm{mg} \mathrm{m}^{-1}\right)$ of all peptides were ${ }^{\cdot}$ made in distilled water and kept at $-20^{\circ} \mathrm{C}$. Daily solutions were made in $0.9 \%$ saline and discarded at the end of the experiment. Solutions of indomethacin were made in Trizma base.

Activities of agonists are presented in terms of $\mathrm{pD}_{2}$ and those of antagonists in terms of $\mathrm{pA}_{2}$ or $\mathrm{pA}_{10}$. Data obtained in the absence and in the presence of antagonists or peptidase inhibitors have been compared, by Student's $t$ test for paired samples. Probability values lower than 0.05 were considered to be significant.

\section{Results}

\section{Effects of bombesin and related peptides on isolated organs}

The four isolated organs used in the present study responded to BBS and related peptides with concentration-dependent contractions which developed rapidly; for instance, in the GPUB (Figure 1) and the GPGB (not shown). These contractions were reversible in a few minutes after washing out the peptides. In the other preparations, the RUB (Figure 1) and the RS (not shown), the contractile responses consisted of an initial rapid and late slow phase and took 5 to $8 \mathrm{~min}$ to reach the maximum: they were reversible, but more slowly than those of the tissues from the guinea-pig (Figure 1).

Concentration-response curves were measured with all the bombesin-related peptides agonists in the four tissues by applying consecutively, increasing concentrations of each peptide from threshold to $10^{-5} \mathrm{M}$.

Examples of such curves are shown in Figure 2 for bombesin and neuromedin B. The two peptides showed similar activities in the rat urinary bladder, but bombesin was much more active than neuromedin $B$ on the other three tissues, particularly the GPGB. The other peptides gave concentration-response curves that occupied an intermediate position between bombesin and neuromedin B, and showed parallelism with that of BBS. This is shown in Figure 2 for the GPUB. From such curves, the activities of the various peptides were compared with that of BBS as mentioned under Methods.

\section{Order of potency of bombesin homologues and fragments}

Relative affinities (expressed as a percentage of that of BBS) of some homologues and fragments of bombesin, including those already tested by Regoli et al. (1988) are presented in Table 2. In all preparations, bombesin and its fragment Ac-BBS (6-14) were the most potent stimulants. The other fragment, BBS (6-14) was also very active on the RUB and the GPUB, but less active than bombesin on the others. Neuromedin $B$ was as active as BBS on the RUB, while showing little activity on the other three preparations (see also Figure 2). The affinities of bombesin homologues in the GPUB and the GPGB were very similar and the rank order of potency of the investigated peptides was as follows: $\mathrm{BBS}>\mathrm{GRP}=\mathrm{Lit} \geqslant \mathrm{NMC} \gg$ $\mathrm{NMB}>\left[\mathrm{Phe}^{6}\right]-\mathrm{NMC}$.

The rat stomach showed some differences compared to the GPUB and GPGB. Firstly, NMC was much less active than BBS; however, NMB was a full agonist with almost $10 \%$ of

Table 1 Primary structure of bombesin-related peptides

\begin{tabular}{|c|c|c|c|c|c|c|c|c|c|c|c|c|c|c|c|}
\hline & 1 & 2 & 3 & 4 & 5 & 6 & 7 & 8 & 9 & 10 & 11 & 12 & 13 & 14 & \\
\hline Bombesin (BBS) & pGlu & Gln & Arg & Leu & Gly & Asn & Gln & Trp & Ala & Val & Gly & His & Leu & Met & $\mathbf{N H}_{2}$ \\
\hline BBS (6-14) & & & & & & - & - & - & - & 一 & - & - & - & - & 一 \\
\hline Ac-BBS (6-14) & & & & & Ac & - & - & - & - & - & - & - & - & - & - \\
\hline Ac-[D-Phe $\left.{ }^{12}\right]$ BBS (6-14) & & & & & Ac & - & - & 一 & - & - & - & DPhe & - & - & - \\
\hline Neuromedin C (NMC) & & & & & - & - & His & - & - & - & - & - & - & - & - \\
\hline$\left[\mathrm{Phe}^{6}\right]-\mathrm{NMC}$ & & & & & - & - & His & - & - & Phe & - & - & - & - & - \\
\hline Neuromedin B (NMB) & & & & & - & - & Leu & - & - & Thr & - & - & Phe & - & - \\
\hline Litorin & & & & & & pGlu & - & - & - & 一 & 一 & 一 & Phe & 一 & - \\
\hline & & 15 & 16 & 17 & 18 & 19 & 20 & 21 & 22 & 23 & 24 & 25 & 26 & 27 & \\
\hline GRP (human) & & R-Tyr & Pro & Arg & - & - & His & - & - & - & - & - & - & - & $\mathrm{NH}_{2}$ \\
\hline Ac-GRP (20-26) & & & & & & Ac & His & - & - & - & - & - & 一 & $\mathrm{NH}_{2}$ & \\
\hline Ac-GRP $(20-26) \mathrm{OCH}_{3}$ & & & & & & Ac & His & - & - & - & - & - & - & $\mathrm{OCH}_{3}$ & \\
\hline Ac-GRP $(20-26) \mathrm{OC}_{2} \breve{H}_{5}$ & & & & & & Ac & His & - & - & - & - & - & - & $\mathrm{OC}_{2} \mathrm{H}_{5}$ & \\
\hline
\end{tabular}


a

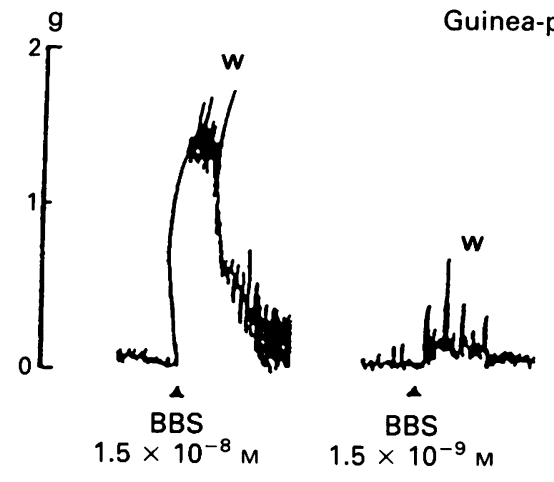

b

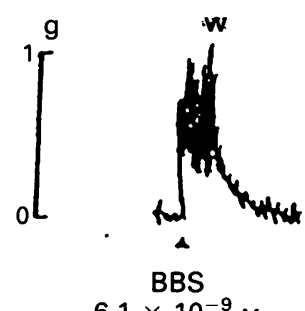

$6.1 \times 10^{-9}$

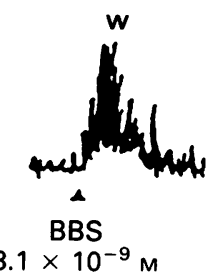

Guinea-pig urinary bladder
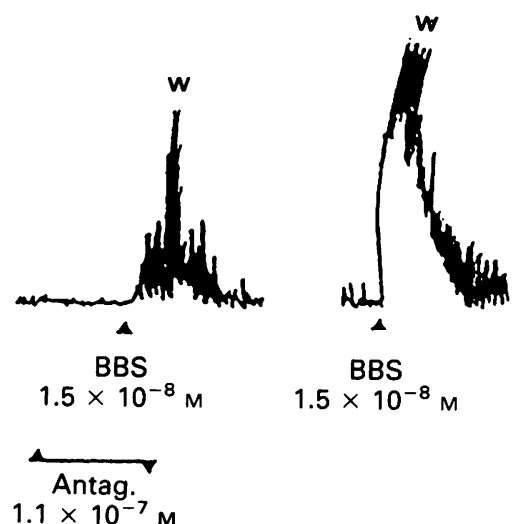

$1.1 \times 10^{-7}$
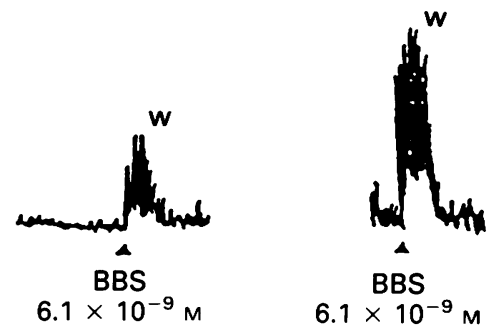

BBS

Antag.
$1.1 \times 10^{-8} \mathrm{M}$

Rat urinary bladder

c

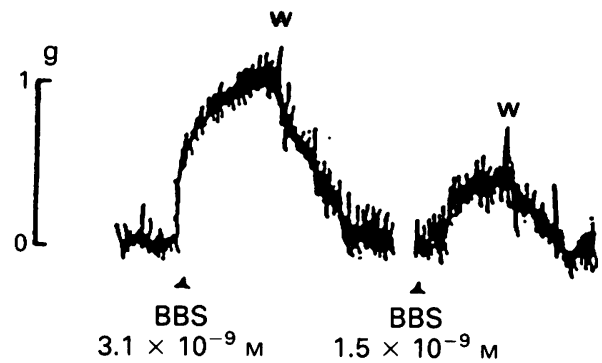

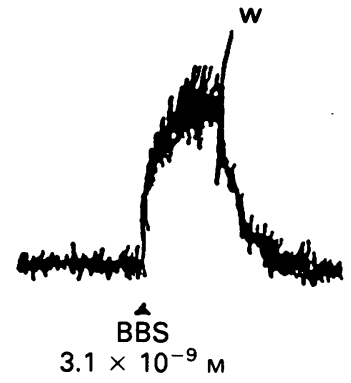

Antag.
$1.1 \times 10^{-7} \mathrm{M}$

$10 \mathrm{~min}$

Figure 1 Myotropic effects of bombesin (BBS) obtained on the guinea-pig urinary bladder (a and b) and the rat urinary bladder (c). In (a) and (b), the first two tracings represent the contractile effect of BBS when the peptide is kept in contact with the tissue for 4 min.

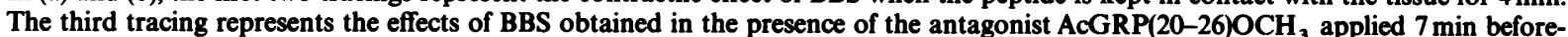
hand. The fourth tracing shows the effect of BBS, measured $30 \mathrm{~min}$ later and indicates that the effect of the antagonist is reversible. Tracings shown in (c) were obtained on the rat urinary bladder with BBS in the absence (first two tracings) and presence of the antagonist (third tracing). At the point indicated by $\mathbf{W}$, the bath fluid was replaced with fresh Tyrode solution. Abscissa scale: time in min; ordinate scale: changes of tension in $\mathbf{g}$.

the activity of BBS: it was therefore more active than in the GPUB and especially in the GPGB. The order of potency of these peptides on the RS was: NMC $>$ BBS $>$ GRP = Lit $>$ NMB $>\left[\mathrm{Phe}^{6}\right]-\mathrm{NMC}$.

In the RUB, two major differences were observed, the high affinity of neuromedin B which was equivalent to bombesin and a weak potency of GRP. In this preparation, the order of potency of BBS-related peptides was $\mathrm{BBS}=\mathrm{NMB}>$ Lit $>$ NMC $>\left[\mathrm{Phe}^{6}\right]-\mathrm{NMC}=\mathrm{GRP}$.

This order of potency of agonists was different from those obtained in the other preparations, especially the GPUB and GPGB. The RS appeared to occupy an intermediate position, because of the high activity of NMC and a relatively high residual activity of NMB. Moreover, the two fragments of BBS showed exceptionally high maximal effects in this tissue (Table 2).

\section{Affinities and competitivity of antagonists}

Three analogues of the gastrin releasing peptide and an analogue of Ac-BBS (6-14) were evaluated as antagonists in the four preparations. As shown in Table 3, AC-[D-Phe $\left.{ }^{12}\right]-B B S$ (6-14) and Ac-GRP (20-26) were found to be inactive both as 

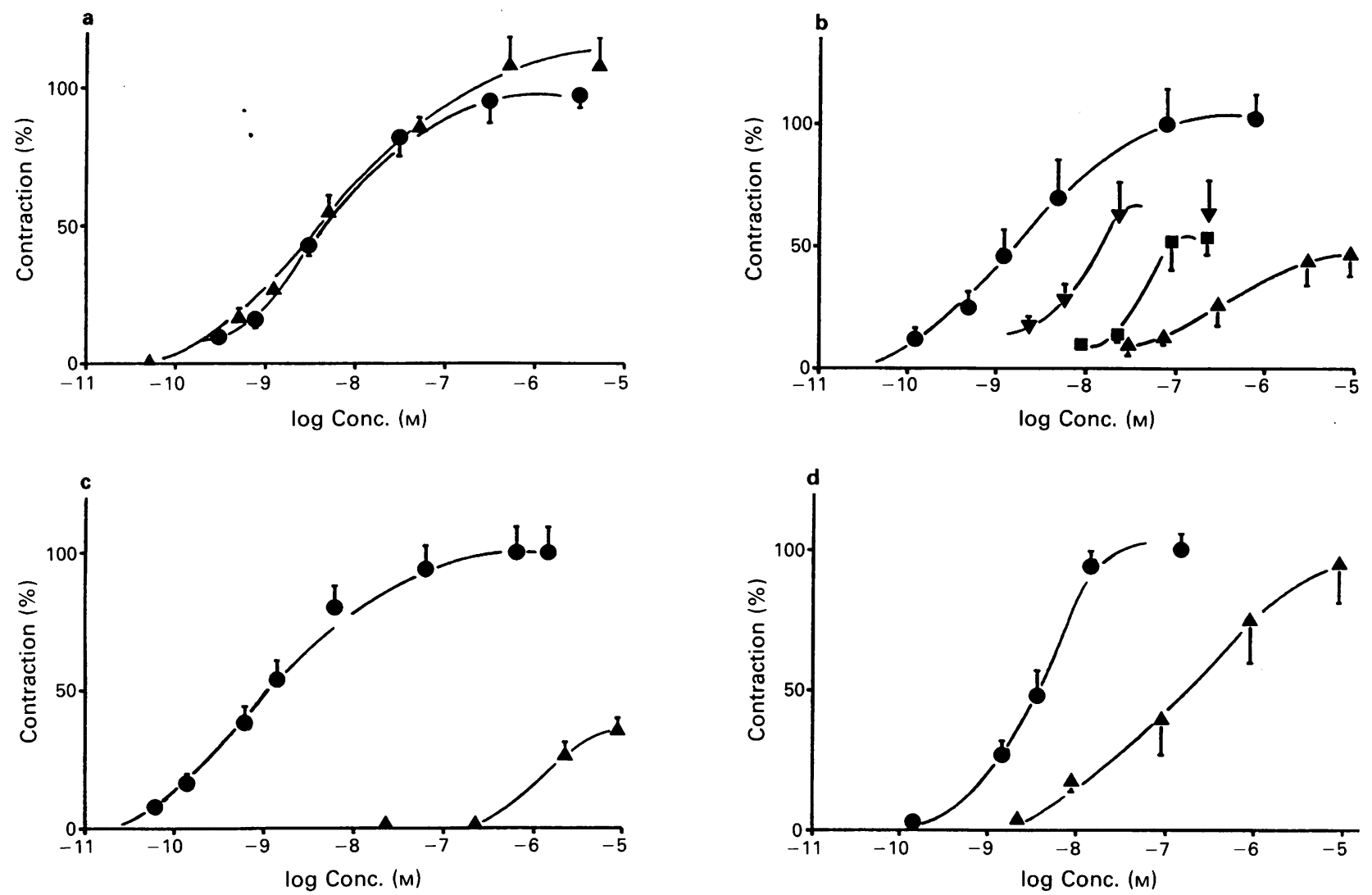

Figure 2 Concentration-response curves of bombesin $(\Theta)$ and neuromedin $B(\Delta)$ obtained in four isolated organs, and neuromedin C $(\boldsymbol{\square})$ and GRP $(\nabla)$ in the guinea-pig urinary bladder. Abscissa scale: - $\log$ of the concentration of agonist; ordinate scale: biological responses (contraction) as a percentage of that of bombesin. Points are mean and vertical bars are the s.e. of at least 6 determinations obtained in different tissues.

stimulants and as antagonists: conversely, Ac-GRP (20-26) $\mathrm{OCH}_{3}$ and Ac-GRP (20-26) $\mathrm{OC}_{2} \mathrm{H}_{5}$ exerted a potent inhibitory effect against bombesin on the RS, the GPGB and the GPUB, showing $\mathrm{pA}_{2}$ values of almost 8.0 ; the two compounds were however completely inactive on the RUB. $\mathrm{pA}_{10}$ was measured for the two compounds on the RS and the GPUB in order to establish the type of antagonism from the difference $\mathrm{pA}_{2}-\mathrm{pA}_{10}$. As shown in Table 3, the differences were near to 1.0 for the GPUB, suggesting that both antagonists exerted a competitive type of inhibition. This was confirmed by the Schild plot (Figure 3) which was linear and showed a slope of 0.981 . The $\mathrm{pA}_{2}-\mathrm{pA}_{10}$, evaluated in the RS, were 1.10 and 0.92 respectively for Ac-GRP $(20-26) \mathrm{OCH}_{3}$ and Ac-GRP (20-26) $\mathrm{OC}_{2} \mathrm{H}_{5}$.
When tested against substance $P$, bradykinin and angiotensin II on the GPUB, Ac-GRP (20-26) $\mathrm{OCH}_{3}$ and Ac-GRP (20-26) $\mathrm{OC}_{2} \mathrm{H}_{5}$ were found to be inactive: the antagonists appeared therefore to be specific for bombesin receptors.

The tracings of Figure 1 show that one of the peptides (AcGRP (20-26) $\mathrm{OCH}_{3}$ ) had no direct effect at the concentration of $1.1 \times 10^{-8} \mathrm{M}$ or higher $\left(1.1 \times 10^{-7} \mathrm{M}\right)$ : the antagonist did not exert any antagonistic effect on the RUB at a concentration of $1.1 \times 10^{-7} \mathrm{M}$ and higher (data not shown). These findings and other similar obtained in the other two preparations (RS and GPGB) suggested the existence of at least two different receptors for bombesin and related peptides in peripheral organs.

Table 2 Apparent affinities $\left(\mathrm{pD}_{2}\right)$, relative affinities (RA) and maximum responses $\left(\alpha^{\mathrm{E}}\right.$, expressed in fraction or multiple of that of bombesin) of bombesin-related peptides in four isolated organs

\begin{tabular}{|c|c|c|c|c|c|c|c|c|c|c|c|c|}
\hline & \multicolumn{3}{|c|}{$R U B$} & \multicolumn{3}{|c|}{$G P U B$} & \multicolumn{3}{|c|}{$G P G B$} & \multicolumn{3}{|c|}{$R S$} \\
\hline & $\mathrm{pD}_{2}$ & $\mathbf{R A}$ & $\alpha^{\mathbf{E}}$ & $\mathrm{pD}_{2}$ & $\mathbf{R A}$ & $\alpha^{\mathrm{E}}$ & $\mathrm{pD}_{2}$ & $\mathbf{R A}$ & $\alpha^{\mathbf{E}}$ & $\mathrm{pD}_{2}$ & RA & $\alpha^{\mathbf{E}}$ \\
\hline Bombesin (BBS)* & 8.33 & 100 & 1.0 & 8.83 & 100 & 1.0 & 8.92 & 100 & 1.0 & 8.43 & 100 & 1.0 \\
\hline Litorin* & 8.20 & 74 & 0.8 & 8.36 & 34 & 1.3 & 8.53 & 41 & 0.9 & 8.26 & 68 & 1.0 \\
\hline Neuromedin C (NMC)* & 7.80 & 30 & 0.7 & 7.91 & 12 & 0.6 & 7.93 & 10 & 0.9 & 8.62 & 155 & 1.2 \\
\hline$\left[\mathrm{Phe}^{6}\right]-\mathrm{NMC}$ & 7.24 & 8 & 0.6 & 6.24 & 0.3 & 0.5 & 6.12 & 0.2 & 1.1 & 6.72 & 2 & 1.0 \\
\hline Neuromedin B (NMB)* & 8.29 & 91 & 1.1 & 6.71 & 0.8 & 0.5 & & P.Ag. & & 7.26 & 7 & 1.0 \\
\hline GRP (human)* & 7.13 & 6 & 0.8 & 8.20 & 23 & 0.6 & 8.68 & 58 & 0.8 & 8.26 & 68 & 1.0 \\
\hline BBS $(6-14)$ & 8.52 & 155 & 1.0 & 8.92 & 123 & 1.0 & 8.53 & 41 & 0.9 & 8.16 & 54 & 2.0 \\
\hline Ac-BBS $(6-14)$ & 8.48 & 141 & 1.2 & 8.83 & 100 & 1.3 & 9.20 & 191 & 1.0 & 8.68 & 178 & 1.7 \\
\hline
\end{tabular}

RUB: rat urinary bladder; GPUB: guinea-pig urinary bladder; GPGB: guinea-pig gall bladder; RS: rat stomach. GRP: gastrin releasing peptide; P.Ag.: partial agonist.

$\mathrm{pD}_{2}:-\log$ concentration of agonist that produces $50 \%$ of the maximal effect. RA: relative affinities expressed as a percentage of that of $\mathrm{BBS}=$ bombesin $=100$.

* Data from Regoli et al., 1988.

Each value was obtained from at least 10 determinations. 
Table 3 Antagonistic effects $\left(\mathrm{pA}_{2}\right.$ and $\left.\mathrm{pA}_{10}\right)$ of bombesin antagonists against bombesin on 3 of the 4 preparations

\begin{tabular}{|c|c|c|c|c|c|c|c|c|}
\hline \multirow[b]{3}{*}{ Antagonists } & \multicolumn{8}{|c|}{ Preparations $^{\mathbf{a}}$} \\
\hline & \multirow{2}{*}{$\begin{array}{c}R U B \\
\mathrm{pA}_{2}\end{array}$} & \multirow{2}{*}{$\begin{array}{c}G P G B \\
\mathrm{pA}_{2}\end{array}$} & \multicolumn{3}{|c|}{$R S$} & \multicolumn{3}{|c|}{$G P U B$} \\
\hline & & & $\mathrm{pA}_{2}$ & $\mathrm{pA}_{10}$ & $\mathrm{pA}_{2}-\mathrm{pA_{10 }}$ & $\mathrm{pA}_{2}$ & $\mathrm{pA}_{10}$ & $\mathrm{pA}_{2}-\mathrm{pA}_{10}$ \\
\hline $\begin{array}{l}\text { AcGRP }(20-26) \mathrm{OCH}_{3} \\
\text { AcGRP }(20-26) \mathrm{OC}_{2} \mathrm{H}_{5} \\
\left.\text { Ac-[D-Phe }{ }^{12}\right]-B B(6-14) \\
\text { Ac-GRP }(20-26)\end{array}$ & $\begin{array}{l}\text { Inact. } \\
\text { Inact. } \\
\text { Inact. } \\
\text { Inact. }\end{array}$ & $\begin{array}{c}8.07 \\
8.07 \\
\text { Inact. } \\
\text { ND }\end{array}$ & $\begin{array}{r}7.94 \\
7.55 \\
\text { Inact. } \\
\text { Inact. }\end{array}$ & $\begin{array}{l}6.84 \\
0.92\end{array}$ & $\begin{array}{l}1.10 \\
0.92\end{array}$ & $\begin{array}{l}7.95 \\
7.95 \\
\text { Inact. } \\
\text { Inact. }\end{array}$ & $\begin{array}{l}6.96 \\
6.94\end{array}$ & $\begin{array}{l}0.99 \\
1.01\end{array}$ \\
\hline
\end{tabular}

abbreviations as in Table 2.

Inact.: inactive; ND: not determined. All data were calculated from at least 6 determinations.

$\mathrm{pA}_{10}$ : - $\log$ concentration of antagonist that reduces the effect of a dose of agonist 10 times higher than that of a single dose.

\section{Specificity of the effects of bombesin in four preparations}

Several antagonists or inhibitors of other naturally occurring agents (e.g. acetylcholine, angiotensin II, bradykinin, etc.) were used to determine the specificity of the responses of the RUB, RS, GPGB and GPUB to bombesin. Thus, atropine $\left(1.5 \times 10^{-7} \mathrm{M}\right)$, methysergide $\left(7.1 \times 10^{-6} \mathrm{M}\right)$, the kinin $\mathrm{B}_{2}$

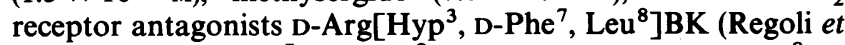
al., 1990) $\left(1.8 \times 10^{-7} \mathrm{M}\right)$, [Leu $\left.{ }^{8}\right]$ angiotensin II $\left(8.4 \times 10^{-8} \mathrm{M}\right)$, as well as the inhibitors of the arachidonic acid cascade, namely indomethacin $\left(7.0 \times 10^{-6} \mathrm{M}\right)$ and BW-755C $\left(1.1 \times 10^{-5} \mathrm{M}\right)$ were found to be inactive against bombesin $\left(3.9 \times 10^{-9} \mathrm{M}\right)$, while blocking the effects of acetylcholine $\left(1.5 \times 10^{-5} \mathrm{M}\right)$, 5-hydroxytryptamine $\left(6.4 \times 10^{-6} \mathrm{M}\right)$, bradykinin $\left(8.1 \times 10^{-9} \mathrm{M}\right)$ and angiotensin II $\left(9.1 \times 10^{-8} \mathrm{M}\right)$ respectively. Similar results were obtained with the same antagonists, applied at the same concentrations and tested against bombesin $\left(3.9 \times 10^{-9} \mathrm{M}\right)$ on the RUB. Again, the antagonists were found to be active in blocking the effects of the corresponding agonists, applied at the same concentrations as in the RS. As already mentioned, the responses of the RS, the GPUB and the GPGB to bombesin were blocked by two bombesin antagonists, while that of the RUB was not affected.

\section{Peptidase inhibitors}

Captopril $\left(4.6 \times 10^{-6} \mathrm{M}\right)$, thiorphan $\left(1.0 \times 10^{-6} \mathrm{M}\right)$ and bestatin $\left(8.1 \times 10^{-6} \mathrm{M}\right)$ were tested to evaluate the possible interference by the angiotensin converting enzyme or other peptidases and by the bestatin-sensitive aminopeptidases on the biological response of the RUB, GPUB and RS to bombesin and its fragments. None of these inhibitors were found to be active in reducing or increasing the effects of bombesin, BBS (6-14) or Ac-BBS (6-14) in any of the preparations. These findings suggest that the three tissues do not contain

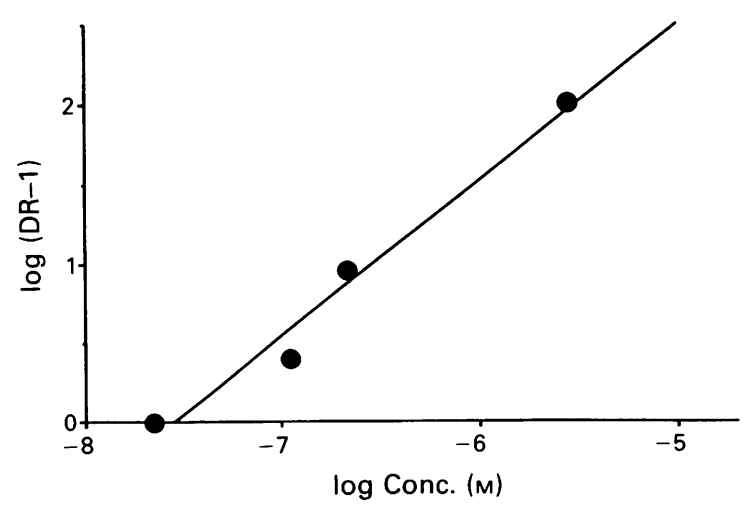

Figure 3 Schild plot of AcGRP (20-26) $\mathrm{OC}_{2} \mathrm{H}_{5}$ against bombesin on the guinea-pig urinary bladder. Abscissa scale: log molar concentration of the antagonist; ordinate scale: $\log (D R-1)$ of the agonist. Slope $=0.98$. active peptidases that are able to hydrolyse bombesin-related peptides.

\section{Discussion}

The present study was directed to identifying and characterizing bombesin receptors in peripheral organs. Four isolated tissues were chosen from several pharmacological preparations (Broccardo et al., 1975) that have been shown to be sensitive to bombesin and related peptides. The major reason for the choice of the RUB, GPUB, GPGB and RS was their high sensitivity to bombesin, described and documented by Girard et al. (1984) for the RS, and by Mizrahi et al. (1985) for the RUB and GPUB and confirmed recently by FalconieriErspamer et al. (1988) who have also studied the GPGB (Regoli et al., 1988). Indeed, the four preparations showed $\mathrm{pD}_{2}$ values for bombesin between 8.3 and 8.9 (RUB 8.33, GPUB 8.83, GPGB 8.92, RS 8.43).

Bombesin and related peptides evoked rapid contractions of the GPUB (Figure 1) that were not maintained at a stable plateau and faded even if the peptide was kept in contact with the tissue. Similar effects of bombesin were observed in the GPGB. In these tissues, concentration-response curves can only be measured by consecutive applications of the peptides in increasing concentrations. When enough time $(20-40 \mathrm{~min})$ is left between two doses, full sensitivity is maintained and desensitization can be avoided. Contractile effects of bombesin or related peptides in the rat urinary bladder (Figure 1) and the rat stomach developed more slowly and persisted at stable plateaux such that cumulative concentration-response curves could be measured in these preparations. In the present study however, the curves were measured by the same experimental protocol in all tissues to facilitate comparison of data between the various peptides and between the four preparations.

The contractile responses of the four preparations to bombesin appear to be the results of the direct effects of the peptide on the various smooth muscles. In fact, indirect effects by other endogenous agents such as acetylcholine, 5hydroxytryptamine, prostaglandins have been excluded by the use of specific antagonists or inhibitors that reduce or block the effect or the release of the respective stimulants without influencing the responses to bombesin and related peptides. The possible interference by bombesin with receptors for neurokinins, kinins and angiotensin was excluded by the use of specific antagonists for each peptide. The present results confirm a previous specificity study by Girard et al. (1984) on the RS and by Mizrahi et al. (1985) on the RUB and the GPUB.

Bombesin and related peptides appear to be fairly well protected from the degradation by proteases sensitive to captopril, thiorphan or bestatin. These findings suggest that bombesin-like peptides may not be inactivated by the converting enzyme, or enkephalinase, or the aminopeptidase sensitive to bestatin, in contrast to other peptides, for instance substance $\mathrm{P}$, the myotropic activity of which in the rat urinary bladder was found to be potentiated by captopril (Rouissi et al., 1990b). In a few experiments, performed on the RUB and 
GPUB, it was also found that bombesin and related peptides had the same effects in the absence and in the presence of phosphoramidon, suggesting that endopeptidase 24-11 was not active in these tissues. It is concluded that metabolic degradation by endo and exopeptidases did not interfere with the myotropic effects of bombesin and related peptides in the RUB, GPUB, GPGB and RS.

Characterization of bombesin receptors in the four isolated organs was attempted by measuring the order of potency of agonists and the affinity of antagonists, according to Schild (1973). Several naturally occurring bombesin-related peptides were used, in particular bombesin itself, neuromedin $C$, neuromedin B, litorin and the gastrin-releasing peptide (the human bombesin). We also measured the effect of some bombesin fragments. It was found that the order of potency of agonists was different between the RUB and the other three tissues, since, neuromedin B was much more active on the RUB than on the other preparations. The opposite was true for GRP which is more active on the GPUB, GPGB and RS than on the RUB (Table 2). On the other hand, BBS, bombesin fragments as well as neuromedin $C$ and litorin were found to be nonselective as they showed fairly high affinities in all four preparations (Table 2). Therefore, on the basis of the order of potency of agonists we suggest that there are two different receptors for bombesin, one of which is present in the three preparations (RS, GPUB, GPGB) and the other in the RUB. In molecular terms, it appeared that the replacement of Val in position 10 of bombesin, by Phe (as in [Phe ${ }^{6}$ ] neuromedin C) or by Thr as in neuromedin B favoured the RUB receptor and decreased affinity on the other three preparations.

The hypothesis that bombesin acts on two different receptors was confirmed by the use of two antagonists recently described by Heimbrook et al. (1989). The two compounds were found to be very active (they showed $\mathrm{pA}_{2}$ higher than 7.5) on three preparations, (GPUB, GPGB and RS), while being inactive on the RUB. This represents the best evidence that bombesin acts on two different receptors which were named $\mathrm{BB}_{1}$ and $\mathrm{BB}_{2}$ by Regoli et al. (1988). These names should be changed to $\mathrm{BBS}_{1}$ and $\mathrm{BBS}_{2}$ to be consistent with the peptide nomenclature utilized by Falconieri-Erspamer $e t$ al. (1988) and adopted in the present paper.

Different orders of potency of agonists and different affinities of antagonists have also been reported for other tests, for instance the rat pancreas secretion which is almost insensitive to neuromedin B (Jensen et al., 1984; 1988a; Otsuki et al., 1987). In binding assays, Von Schrenck et al. (1989) have shown the existence of two bombesin binding sites, one of which is to be found in the rat oesophagus and shows high affinity for bombesin and neuromedin B, while the other (in the rat pancreas) shows high affinity for bombesin and very little for neuromedin B (Jensen et al., 1988). Furthermore, Severi et al. (1990) have obtained good evidence that the rat gastric smooth muscle cells contain two different receptor sites. All together, the present results and recent findings in other laboratories suggest that bombesin and related peptides exert their contractile or secretory effects by activating at least two different receptor types.

We acknowledge the excellent secretarial work of Mrs C. Théberge and the technical assistance of $M$. Boussougou. The experimental work presented in this paper has been accomplished with the financial help of the Medical Research Council of Canada (MRCC) and of the Quebec Heart and Shock Foundation. F.N. is recipient of a student grant from the Georges Phénix Foundation, S.D. and G.D. are fellows of the Fonds de la Recherche en Santé du Québec and D.R. is a Career Investigator of the MRCC.

\section{References}

ANASTASI, A., ERSPAMER, V. \& BUCCI, H. (1971). Isolation and structure of bombesin and alytesin, two analogous active peptides from the skin of the European amphibians "bombina" and "alytes". Experientia, 27, 166-167.

ANASTASI, A., ERSPAMER, V. \& ENDEAN, R. (1975). Amino acid composition and sequence of litorin, a bombesin-like nonapeptide from the skin of the Australian frog, Litoria aurea. Experientia, 31, 510-511.

BERTACCINI, G., ERSPAMER, V. \& IMPICCIATORE, H. (1973). The action of bombesin on gastric secretion of the dog and rat. Br. J. Pharmacol., 49, 437-444.

BROCCARDO, M., FALCONIERI-ERSPAMER, P., MELCHIORRI, P. \& NEGRI, L. (1975). Relative potency of bombesin-like peptides. Br. J. Pharmacol., 55, 221-227.

BROWN, M., RIVIER, J. \& VALE, W. (1977). Bombesin: potent effect on thermoregulation in the rat. Science, 196, 988-990.

DRAPEAU, G. \& REGOLI, D. (1988). Synthesis of bradykinin analogs. Methods in Enzymology, 163, 263-272.

ERSPAMER, V., ERSPAMER, G.F. \& INSELVINI, M. (1970). Some pharmacological actions of alytesin and bombesin. J. Pharm. Pharmacol., 22, 875-876.

ERSPAMER, V. \& MELCHIORRI, P. (1973). Active polypeptides of the amphibian skin and their synthetic analogs. Pure Appl. Chem., 35, $463-493$.

FALCONIERI-ERSPAMER, G., SERVINI, C., ERSPAMER, V., MELCHIORRI, P., DElle faVe, G. \& NAKAGIMA, T. (1988). Parallel bioassay of 27 bombesin-like peptides on 9 smooth muscle preparations. Structure-activity relationships and bombesin receptor subtypes. Regulatory Peptides, 21, 1-11.

GIRARD, F., BACHELARD, H., ST-PIERRE, S. \& RIOUX, F. (1984). The contractile effect of bombesin, gastrin releasing peptide and various fragments in the rat stomach strip. Eur. J. Pharmacol., 102, 489-497.

HEIMBROOK, D.V., SAARI, W.P., BALISHIN, N.L., FRIEDMAN, A., MOORE, K.S., RIEMEN, M.W., KIEFER, D.M., ROTBERG, N.S. WALLEN, J.W. \& OLIFF, A. (1989). Carbonyl-terminal modification of a gastrin releasing peptide derivative generates potent antagonists. J. Biol. Chem., 264, 11258-11262.

JENSEN, J.T., JONES, S.W., FOLKERS, K. \& GARDNER, J.D. (1984). A synthetic peptide that is a bombesin receptor antagonist. Nature, 309, 61-63.
JENSEN, R.T., COY, D.H., SAEED, Z.A., HEINZ-ERIAN, P., MANTEY, S. \& GARDNER, J.D. (1988a). Interaction of bombesin and related peptides with receptors on pancreatic acinar cells. Ann. New York Acad. Sci., 547, 138-149.

JENSEN, R.J., HEINZ-ERIAN, P., MORAN, T., MONTEY, S.A., JONES, S.W. \& GARDNER, J.D. (1988b). Characterization of ability of various substance $P$ antagonists to inhibit action of bombesin. Am. J. Physiol., 254, G883-G890.

MCDONALD, T.J., JORNVALL, H., NILSSON, G., VAGNE, M., GHATEI, M., BLOOM, S.R. \& MUTT, V. (1979). Characterization of a gastrin releasing peptide from porcine nonantral gastric tissue. Biochem. Biophys. Res. Commun., 90, 227-233.

MINAMINO, N., KANGAWA, K. \& MATSUO, H. (1984). Neuromedin C: a bombesin-like peptide identified in porcine spinal cord. Biochem. Biophys. Res. Commun., 119, 14-20.

MINAMINO, N., KANGAWA, K. \& MATSUO, H. (1983). Neuromedin B a novel bombesin-like peptide identified in porcine spinal cord. Biochem. Biophys. Res. Commun., 114, 541-548.

MIZRAHI, J., DION, S., D'ORLEANS-JUSTE, P. \& REGOLI, D. (1985). Activities and antagonism of bombesin on urinary smooth muscles. Eur. J. Pharmacol., 111, 339-345.

OTSUKI, M., FUJII, M., NAKAMURA, T., TANI, S., OKA, T., BOLA, S. \& YAJIMA, H. (1987). Action of neuromedin B and neuromedin C on amylase release from isolated rat pancreatic acini. Pancreas, 2, 252-257.

REGOLI, D., DION, S., RHALEB, N.-E., DRAPEAU, G., ROUISSI, N. \& D'ORLEANS-JUSTE, P. (1988). Receptors for neurokinins, tachykinins and bombesin: a pharmacological study. Ann. N.-Y. Acad. Sci., 547, 158-173.

REGOLI, D., RHALEB, N.-E., DION, S. \& DRAPEAU, G. (1990). New selective bradykinin receptor antagonists and bradykinin $\mathbf{B}_{2}$ receptor characterization. Trends Pharmacol. Sci., 11, 156-161.

ROUISSI, N., NANTEL, F., DRAPEAU, G., RHALEB, N.-E., DION, S. \& REGOLI, D. (1990a). Inhibitors of peptidases: how they influence the biological activities of substance $P$, neurokinins, kinins and angiotensins in isolated vessels. Pharmacology, 40, 185-195.

ROUISSI, N., NANTEL, F., DRAPEAU, G., RHALEB, N.-E., DION, S. \& REGOLI, D. (1990b). Inhibitors of peptidases: how they influence the biological activities of substance $P$, neurokinins, kinins and angiotensins in the guinea-pig, hamster and rat urinary bladders. Pharmacology, 40, 186-204. 
SCHILD, H.O. (1947). pA, a new scale for the measurement of drug antagonism. Br. J. Pharmacol. Chemother., 2, 251-258.

SCHILD, H.O. (1949). pA and competitive drugs antagonism. Br. J. Pharmacol. Chemother., 4, 277-280.

SCHILD, H.O. (1973). Receptor classification with special reference to .beta-adrenergic receptors. In Drug Receptors, ed. Rang, H.P. pp. 29-36. Baltimore: University Park Press.

SEVERI, C., GRIDER, J.R. \& MAKHLOUF, G.H. (1988). Identification of separate bombesin and substance $P$ receptors on isolated muscle cells from canine gallbladder. J. Pharmacol. Exp. Ther., 245, 195198.
SEVERI, C., JENSEN, R.J., TORSOLI, A. \& DELLE FAVE, G. (1990). Evidence for subtypes of receptors for bombesin-related peptides on gastric smooth muscle cells. Gastroenterology, 98, A523.

VANE, J.R. (1957). A sensitive method for the assay of 5hydroxytryptamine. Br. J. Pharmacol. Chemother., 12, 344-349.

VON SCHRENCK, T., HEINZ-ERIAN, P., MORGAN, T., MANTEY, S.A., GARDNER, J.D. \& JENSEN, R.T. (1989). Neuromedin B receptor in eophagus: evidence for subtypes of bombesin receptors. Am. J. Physiol., 256, G747-G758.

(Received April 26, 1990

Revised October 12, 1990 Accepted December 19, 1990) 